Technological University Dublin ARROW@TU Dublin

2020

\title{
Corporate Governance, Measurement of
}

Maeve O'Connell

maeve.oconnell@tudblin.ie,maeve.oconnell@tudublin.ie

Anne Marie Ward

University of Ulster

Follow this and additional works at: https://arrow.tudublin.ie/buschacart

Part of the Accounting Commons

\section{Recommended Citation}

O'Connell M., Ward A.M. (2020). Corporate Governance, Measurement of. In:( Idowu S., Schmidpeter R., Capaldi N., Zu L., Del Baldo M., Abreu R. (eds)) Encyclopedia of Sustainable Management. Springer.

This Article is brought to you for free and open access by the School of Accounting and Finance at ARROW@TU Dublin. It has been accepted for inclusion in Articles by an authorized administrator of ARROW@TU Dublin. For more information, please contact arrow.admin@tudublin.ie, aisling.coyne@tudublin.ie, gerard.connolly@tudublin.ie. 


\section{Corporate Governance, Measurement of}

Maeve O’Connell

Technological University Dublin

Aungier Street

Dublin D02 HW71

maeve.oconnell@tudublin.ie
Anne Marie Ward

Ulster University

Newtownabbey

Co. Antrim, BT41 3NX

am.ward@ulster.ac.uk

\section{Synonyms}

Corporate governance bundles, Corporate governance indices, Corporate governance rating systems.

\section{Definition/Description}

The increased focus on good governance and the development of best practice guidelines, often supported by legislation, has been in response to corporate scandals, such as Enron and Worldcom in the early 2000s, and the 2008 banking crisis. Good governance is increasingly recognised as a process where the 'best practices' of yesterday become the standard practices of today. This increased focus has also coincided with a worldwide movement for corporate reporting on sustainability and corporate social responsibility (CSR) issues and a growing demand within the investment industry for investment products that are socially responsible (Benn and Dunphy 2013). Sustainable development is now part of the best practice model of corporate governance. There is a more equal recognition of stakeholders' interests and the role of not only economic, but also social and environmental issues in laying the foundations for a new long-term model of economic growth. This is in contrast to the historic governing model that focused on the creation of shareholder value. However, despite increased attention and interest by policymakers and academics alike, a challenge that has not been unanimously resolved is the definition and measurement of 'good corporate governance'. This chapter evaluates the main approaches to the measurement of corporate governance.

\section{Why Measure Quality Corporate Governance}

There is a strong view by both policymakers and academics alike that there is a positive association between the quality of corporate governance and corporate performance. A measure of corporate governance is required to test this proposition. Considerable attention has been directed at measuring best governance practice in academic literature. This information is then used to examine the link between corporate governance and corporate performance. Corporate performance is measured using profits, dividends, or share price increases. However, the findings are not unanimous, some studies have identified a link (Agrawal and Knowber 1996; MacAvoy and Millstein 2003), however, most show "mixed results without a clear-cut relationship" (Crowther and Aras 2016, p. 14). Tangential evidence from corporations suggest that they also believe there to be benefits from good 
corporate governance as many implemented voluntary changes to their corporate governance in the aftermath of the financial crisis. These steps could reflect a signal by the boards to regulators, the market and the general-public that they appreciate the social impact of weak governance (Carretta et al. 2010)

\section{Indicators of Quality Corporate Governance}

There are two main considerations regarding measuring governance quality, first identifying measures of governance and second the variables employed as proxies for the measures identified.

Sources of information on good corporate governance: Governance requirements arise from four sources. 1. The requirements of the individual corporation's founding documents and other contractual documents. 2. Corporate law within the operational jurisdiction. 3. Relevant corporate codes of conduct and 4 . The requirements of regulators. These four sources are not separate and distinct as each influence and have been influenced by each other through the cultural, political, social and historical circumstances of each country in which the corporate operates. For example, following the global financial crisis and banking failures in 2008 many jurisdictions introduced new laws and regulations to strengthen corporate governance. These changes were a direct response to a cultural change in the political and public perceptions of the role and impact of regulators and corporations on wider society and taxpayers.

Measures of good corporate governance: Researchers and regulators have attempted to identify "best practice" measures. Many of these measures are included in corporate law or in corporate governance codes. Examples of measurable variables that could be included in an index include CEO duality, proportion of non-executive directors, having a remuneration committee, a nominations committee, a risk committee, an audit committee, etc. Indeed, it would be expected that recommendations under corporate governance codes and corporate law would be included as a minimum. Examples of the criteria used by two of the main index providers are now outlined in brief. Most indices identify a number of measurable indicators of good corporate governance and classify them into different areas. These areas typically centre on board structure, equity structure, compensation, audit and ownership (FTSE Research 2005). For example, ISS collect information and analyse it into four components of good corporate governance (ISS 2019b). Component one evaluates Board Structure, and includes information on board composition, composition of committees, board practices, board policy and diversity. Component two evaluates 'Compensation Programs'. This includes information on pay for performance, communications and disclosures, nonexecutive pay and termination. Component three evaluates 'Shareholder Rights', including information on one-share-one-vote, takeover defences, meetings, voting rights and procedures. Finally, component four evaluates 'Audit and Risk Oversight'. This component includes information on the external auditor, audit and accounting issues. Research has found a relationship between many of these indicators, for example board size, board composition (the fraction of independent directors), and director ownership (proportion of shares owned collectively by all directors) and board effectiveness (Faleye et al. 2011), and 
some evidence that recommendations from index providers to vote "against" proposed executive pay are associated with worse future corporate performance (Carter and Gallani 2019).

\section{Limitations of Measures of Quality Corporate Governance}

A variety of corporate governance indices are used to assess the quality of corporate governance. The indices are not homogenous, there are similarities but also differences in the underlying variables used to measure quality corporate governance. Most indices assume a 'one shoe size fits all' approach, that there is an optimal governance structure and any deviation from this reflects a governance problem. Yet most of these governance indices are based on structural measures that are easily measured. The problem lies in what they are not capturing. Research has identified a number of issues with current measures of quality corporate governance and empirical studies that examine the link between corporate governance, using these rating measures, and performance. The problems identified include, lack of inclusion of non-financial measures, omitted variables, use of a bundled index approach, endogeneity and board dynamics. These are now discussed in turn.

Non-financial indicators: An underlying assumption of many academic studies is that corporates pursue financial outcomes as their primary objective and shareholders are the primary stakeholder. This approach does not consider performance in terms of the impact the corporate has on society and the environment. It is argued that this narrow approach is no longer valid given the increasing focus on the wider impact of weak corporate governance, particularly following the financial crisis of 2008, on society, communities and taxpayers (Willems et al. 2012). Non-profit research has attempted to address this, as financial outcomes are only one measure of non-profit success, however, identifying a method to assess and compare corporate performance is more difficult, and there is no agreed measure or composite of measures of corporate performance (Newton 2015).

Omitted variables: Research has identified that some characteristics that are not included in indices contribute to effective governance, such as the quality of board meeting discussions (Forbes and Milliken 1999; Maharaj 2009; Wan and Ong 2005) and the indices often fail to account for the impact of the external context, for example, country, legal system, corporate factors, and industry. It is argued that optimal governance may vary across corporations and industry types, that there is no 'one-size-fits-all' model (Vagliasindi 2008) and though different industries or countries can learn from each other's governance approaches they cannot simply apply an external governance model to their own industry or country (Letza et al. 2010; Petrovic 2008).

Criticism of a bundled approach: Indices are typically constructed from a wide range of indicators of corporate governance. They are criticised for using too many variables rather than focusing on the variables that 'really matter', a 'kitchen-sink-approach' (Bebchuk et al. 2009). They are criticised on the appropriateness of the selected variables 
and the weighting attached to each variable. Existing ratings either arbitrarily sum up several indicators into a single measure (Daines et al. 2010) or employ sophisticated but completely opaque algorithms. Finally, it is argued that indices frequently fail to demonstrate the theoretical justification of the composition of indicators and the weighting of different variables (Schnyder 2012). Despite the weaknesses and criticisms of governance indices, it is argued that reducing the measures included in them is a step in the wrong direction, as it eliminates information about interactions between different corporate governance mechanisms. As Schynyder (2012) concludes, things should be kept as simple as possible, but not simpler.

Endogeneity and board dynamics: Even where a positive link is found between a governance measure and corporate value or performance, the research approach faces a series of criticisms. First is the consensus view that the relationship between governance and corporate performance is endogenous, simply put, there could be an error in the direction of causality, and all variables in governance are endogenous (Vagliasindi 2008). Second, there is often a lack of clarity on the level of analysis, for example, it may not be clear if the variable included is an individual director or the board as a group (Petrovic 2008). Moreover, board dynamics analysis can fail to consider the structural and contextual elements impacting governance and the interplay between these factors (Petrovic 2008).

These issues impact the validity and reliability of governance indices. They make definite 'best practice' claims difficult and may explain some of the contradictory findings in the research with consequent challenges for governance indices (Bebchuk et al. 2013; Dumitrescu and Zakriya 2018). For example, it has proven difficult to show that even sophisticated professional measures of the quality of a corporate's corporate governance system produced by different commercial providers are able to predict future performance (Schnyder, 2012). In addition, corporate governance indices are subject to further criticism in respect of the data collection process.

\section{Data Collection}

A review of the literature identifies three main approaches to gathering data on governance quality: benchmarking disclosures against an index of disclosures that are deemed to reflect governance quality; surveying individuals within the corporation; and measuring the volume of voluntary public disclosures. These are now critiqued in turn.

Benchmarking corporate disclosures to a corporate governance index: Indices to assess governance quality have been created by researchers and professional organisations based on the criteria prescribed by legal, cultural and regulatory requirements. Data is collected by benchmarking the information on corporate governance disclosed in corporations' annual reports and/or website to the index. Coding usually involves awarding a score of one when the measure of quality governance is present and zero if there is no evidence of it. A cumulative score is determined for each corporation. This may be expressed in percentage terms. The higher the percentage the higher the quality of corporate governance. The indices make it easier for investors to assess the quality of corporate governance as the resultant 
score is used to rate corporations relative to each other and over time. The score can also highlight the degree of risk an investor takes when he/she invests in a corporation. There is demand for this form of data collection and several consultancy firms specialise in producing governance indices and collecting data based on these indices for investors. For example, Institutional Shareholder Services (ISS) is the largest provider of information on governance to hedge funds, mutual funds and similar organisations, and provides Governance Quality Scores to its clients. These clients managed investments worth about $\$ 4.2$ trillion in 2019 (ISS 2019a). Corporate governance ratings also serve as inputs into tradable indices (Daines et al. 2010) such as those created by FTSE Group and Standard and Poor. Some of the more widely employed indices include MSCI ESG Metrics, ISS Institutional Shareholder Services Governance Quality Score, Sustainalytics' ESG Risk Ratings, Standard and Poor's Trucost ESG Analysis, Dow Jones Sustainability Index and Business in the Community Corporate Responsibility Index. Indices highlight the importance of quality corporate governance and, through publicising it, put pressure on corporates to conform.

Survey approach: A second approach to calculating data on governance quality is to survey individuals within the corporation. Surveys can either be sent to a single person or to multiple persons within the corporate. These surveys are usually addressed to the CEO or chair of the board, if a single survey is required, or to all board members if a multiple survey approach is adopted. Examples of this method include the Carver Model and the Governing Board Effectiveness Model, where board effectiveness is assessed by analysing the responses of board members to a survey (Carver 1997; Gabris and Nelson 2013). This approach encounters the obvious subjective and unique view of an individual respondent or difficulties in assessing a variety of respondents' perceptions, which can vary widely between individuals (Willems et al. 2012). In addition, self-ratings frequently correlate poorly with other performance measures due to various compounding factors including inflation bias (Eva et al. 2004). Researchers attempting this approach also face the trade-offs between multiple raters within a single corporate and a small sample of participant corporations or the unique views of single raters and a larger sample of corporations, with consequences for the validity and reliability of the results (Cornforth 2001; Willems et al. 2012). These elements are thus costly and difficult, if not impossible, for individual investors, stakeholders or regulators to assess as boards are not required to apply a universal measure of board performance assessment or publish the results of assessments under law or governance codes (Financial Reporting Council 2018).

Volume of voluntary disclosures: Finally, the level of voluntary disclosures by a corporation has also been used as a measure of corporate governance quality (Brennan and Solomon 2008). The assumption is that the greater the volume of additional voluntary material provided on corporate governance, the greater the quality of corporate governance within the corporation. However, inclusion of voluntary disclosures may not add value to an assessment of governance quality as there is evidence that corporate governance quality and voluntary disclosures may in fact be substitutes, with a higher governance quality reducing voluntary disclosures (Brown et al. 2011). 
In summary, there are three main approaches to collecting data on governance quality, first measuring public disclosures against set governance criteria outlined in the relevant governance codes creating indices of governance quality, second measuring organisation governance through surveys of a single respondent, e.g. the chairperson or CEO, or several raters e.g. the entire board, and finally measuring voluntary public disclosures, with this final element sometimes included in governance indices or surveys.

\section{Conclusions}

Current measures are sourced from governance codes of practice, legislation and regulations. These policy documents include recommendations and guidance for corporates and boards based on the literature and industry inputs and provide a practical starting point for assessing governance and developing governance indices (Financial Reporting Council 2018; ICGN 2017). However, it could be argued that corporate governance requires more than compliance with sets of principles or codes of practice, which are often the lowest common denominator for governance standards. Good governance is about human behaviour and the role of corporates in society, how corporates are run and how they relate to their principal stakeholders. Good corporate governance is about compliance in spirit with meaningful quality reporting and transparency for all stakeholders. However, measurement of governance faces considerable challenges including lack of inclusion of non-financial indicators, omitted variables, use of a bundled approach, endogeneity and the relevance of board dynamics. In addition, questions are raised about the appropriateness of some of the data collection techniques. Despite these difficulties and questions about the association between corporate governance and financial performance (Vagliasindi 2008), it is reasonable to conclude that corporate governance matters to a corporate's performance, market valuation and credibility. Corporate governance is seen as a tool to support the achievement of a corporate's goals and strategy and investors are willing to pay a premium for well governed corporates. Therefore, the quest to identify and measure good corporate governance is ongoing and is likely to attract attention from academics and index providers alike.

The advances in corporate governance measurement to date have had a positive impact on corporate governance. The growth of an industry that supplies corporate governance indices is generating a demand for better measures of quality corporate governance. Despite criticisms of corporate governance indices, indices do provide a benchmark that enable changes in corporate governance over time to be monitored. It can be argued that the use of published indices has also impacted on the quality of corporate governance, that peer pressure has contributed to corporations seeking to improve their standing within these indices. That this has resulted in a bunching at the top that diminishes the differences between corporations and reflects increasing compliance with good practice.

\section{Cross-references}


- Cadbury Report (UK)

- CRS Communication and Sustainability

- Directors and CSR

\section{References}

Agrawal, A., and Knowber, C. R. (1996). Firm Performance and Mechanisms to Control Agency Problems between Managers and Shareholders. Journal of Financial and Quantitative Analysis, 31(3), 377-397.

Bebchuk, L., Cohen, A., and Ferrell, A. (2009). What Matters in Corporate Governance? Review of Financial Studies, 22(2), 783-827.

Bebchuk, L. A., Cohen, A., and Wang, C. C. Y. (2013). Learning and the Disappearing Association between Governance and Returns. Journal of Financial Economics, 108(2), 323-348.

Benn, S., and Dunphy, D. (Eds.) (2013). Corporate Governance and Sustainability: Challenges for Theory and Practice. London and New York: Routledge.

Brennan, N. M., and Solomon, J. (2008). Corporate Governance, Accountability and Mechanisms of Accountability: an Overview. Accounting, Auditing and Accountability Journal, 21(7), 885-906.

Brown, P., Beekes, W., and Verhoeven, P. (2011). Corporate Governance, Accounting and Finance: A Review. Accounting and Finance, 51(1), 96-172

Carretta, A., Farina, V., and Schwizer, P. (2010). Assessing Effectiveness and Compliance of Banking Boards. Journal of Financial Regulation and Compliance, 18(4), 356-389

Carter, M. E., and Gallani, S. (2019). Are ISS Recommendations Informative? Evidence from Assessments of Compensation Practices. HBR Working Paper (No. 19-085). Boston, MA: Harvard Business School.

Carver, J. (1997). Boards that make a difference (2nd Edition). San Francisco: Jossey Bass.

Cornforth, C. (2001). What Makes Boards Effective? An Examination of the Relationships between Board Inputs, Structures, Processes and Effectiveness in Non-Profit Organizations. Corporate Governance: An International Review, 9(3), 217-227.

Crowther, D., and Aras, G. (2016). Corporate Governance and Corporate Social Responsibility in Context. In G. Aras and D. Crowther (Eds.), Global Perspectives on Corporate Governance and CSR (pp. 23-64). Surrey, UK: Gower Publishing.

Daines, R. M., Gow, I. D., and Larcker, D. F. (2010). Rating the Ratings: How Good are Commercial Governance Ratings? Journal of Financial Economics, 98(3), 439-461.

Dumitrescu, A., and Zakriya, M. (2019). Governance, Information Flow and Stock Returns: Evidence from a Natural Experiment. SSRN Electronic Journal. http://doi.org/10.2139/ssrn.3170881, accessed $18^{\text {th }}$ March 2019. 
Eva, K. W., Cunnington, J. P., Reiter, H. I., Keane, D. R., \& Norman, G. R. (2004). How can I know what I don't know? Poor self assessment in a well-defined domain. Advances in Health Sciences Education, 9(3), 211-224.

Faleye, O., Hoitash, R., and Hoitash, U. (2011). The Costs of Intense Board Monitoring. Journal of Financial Economics, 101(1), 160-181.

Financial Reporting Council. (2018). The UK Corporate Governance Code (July 2018), 1-15.

Forbes, D. P., and Milliken, F. J. (1999). Cognition and Corporate Governance: Understanding Boards of Directors as Strategic Decision-Making Groups. Academy of Management Review, 24(3), 489-505.

FTSE Research (2005). FTSE ISS Corporate Governance Rating and Index Series - Measuring the Impact of Corporate Governance on Global Portfolios April 2005.

http://www.corporategovernanceboard.se/UserFiles/Archive/462/2005-12-

15_corporate_governance_rating_bilaga_1.pdf, accessed 9th March 2019.

Gabris, G. T., and Nelson, K. L. (2013). Transforming Municipal Boards into Accountable, HighPerforming Teams: Toward a Diagnostic Model of Governing Board Effectiveness. Public Performance and Management Review, 36(3), 472-495.

ICGN (2017). ICGN Global Governance Principles ( $5^{\text {th }}$ Edition). London: International Corporate Governance Network.

ISS (2019a). About ISS. https://www.issgovernance.com/about/about-iss/, accessed 17th March 2019.

ISS Institutional Shareholder Services (2019b). ISS Governance Quality Score. https://www.issgovernance.com/file/products/qualityscore-techdoc.pdf, accessed 17th March 2019.

Letza, S., Kirkbride, J., Sun, X., and Smallman, C. (2010). Corporate Governance Theorising: Limits, Critics and Alternatives. International Journal of Law and Management, 50(1), 17-32.

MacAvoy, P. W., and Millstein, I. M. (2003). The Recurrent Crisis in Corporate Governance. New York: Palgrave Macmillan.

Maharaj, R. (2009). View from the Top: What Directors Say about Board Process. Corporate Governance, 9(3), 326-338.

Newton, A. N. (2015). Executive Compensation, Organizational Performance, and Governance Quality in the Absence of Owners. Journal of Corporate Finance, 30, 195-222.

Petrovic, J. (2008). Unlocking the Role of a Board Director: A Review of the Literature. Management Decision, 46(9), 1373-1392.

Renders, A., Gaeremynck, A., and Sercu, P. (2010). Corporate-Governance Ratings and Company Performance: a Cross-European Study. Corporate Governance: An International Review, 18(2), 87106. 
Schnyder, G. (2012). Measuring Corporate Governance: Lessons from the 'Bundles Approach' (Working Paper No. 438). CBR Research Programme on Corporate Governance. University of Cambridge.

Solomon, J. (2013). Corporate Governance and Accountability (Fourth Edi). John Wiley and Sons, Ltd. Vagliasindi, M. (2008). The Effectiveness of Boards of Directors of State Owned Enterprises in Developing Countries. Policy Research Working Paper 4579. The World Bank.

Wan, D., and Ong, C. H. (2005). Board Structure, Process and Performance: Evidence from PublicListed Companies in Singapore. Corporate Governance: An International Review, 13(2), 277-290.

Willems, J., Huybrechts, G., Jegers, M., Weijters, B., Vantilborgh, T., Bidee, J., and Pepermans, R. (2012). Nonprofit Governance Quality: Concept and Measurement. Journal of Social Service Research, 38(4), 561-578. 